\title{
A CRITICAL DISCOURSE ANALYSIS OF TEACHER-STUDENT INTERACTION IN MA THESIS ORAL EXAMINATION: REFLECTIONS FROM ETHIOPIA
}

\author{
Abebe Asres Mengistu \\ (PhD,Assistant Professor of Applied Linguistics and Communication ) \\ Department of English Language and Literature, \\ College of Social Science and Humanities, University of Gondar
}

DOI: $10.37648 /$ ijrssh.v10i01.037

Received:07 ${ }^{\text {th }}$ November 2019; Accepted:09 ${ }^{\text {th }}$ December, 2019; Published:29 $9^{\text {th }}$ December, 2019

\begin{abstract}
Teacher-student interaction is supposed to be harmonious since it plays an important role in the development of research in higher academic institutions. However, in Ethiopia, teacher-student interaction in the context of MA thesis oral examination remains a serious problem and many conflicts and misunderstandings among instructors and students were reported.This critical discourse analysis study highlightsthe relations of power in teacher-student interaction inthe context of MAthesis oral examination sessions at University of Gondar which is one of the first generation universities in Ethiopia.Five oral examination sessions were audio-recorded and interview sessions with three teachers and three students were conducted to substantiate the audio data. Both the audio and the interview data were transcribed and then analyzed based onFurlough's (1995) critical discourse analysismodel. Based on the analysis, teachers were found powerful authorities in mistreating students by abusing their power. Students on the other hand were foundinferior to teachers who were unable to play their discursive role in presenting their research papers. It is thus recommended that teachers and students in this academic events need to create harmonious relation that would help them to freely share their research experiences. Teachers also should create a conducive atmosphere for students during oral examination sessions so that studentscan present their research work freely and confidently.
\end{abstract}

Key Words: Critical discourse analysis, teacher-student interaction, oral examination

\section{INTRODUCTION}

Aspartial fulfillment of the requirements for a university degree,writingthesis anddefendingit in publichasbeena long-standingpracticein higher academic institutions.Accordingly, MAstudentsare requiredto writetheirthesesonrelevantissuesand presenttheirworkorally in public.Oral events are extremely important events to university students who often come to face uncertainty regarding how the work will be received by the academic authorities assigned to determine the value of students' written and oral performances (Tinkler and Jackson, 2004).

There is much we do not know about the discourse features and power in MA thesis oral examination sessionsas anacademic rite and a special form of academic communication. As to the researcher's understanding of the area, the discourse features and power relations of this communication genre remain unstudied. There are indeed scholars who contend that researches done on the characteristics and structures of 
written dissertations have received considerable attention than researches done on oral examinations. Still researches which have been conducted from the discourse perspective are limited to a small number (Burling, 1997; Grimshaw, 1989; Grimshaw\& Burke, 1994; Hartley, 2000).

In the efforts to locate prior local researches done on the area, the researcher could find out only few works worthy to the purpose of the present research. For example, Zewdu (2012) conducted a research to investigate the research culture of the Department of Foreign Languages and Literature, Addis Ababa University. His focus of investigationwas thetechnical issues involved through the entireprocess of postgraduate training in the department (Zewdu, 2012). Wosenu (2009) also carried out a quantitative research on the examiners' questioning and the relevance of questions in $\mathrm{PhD}$ defense in the context of the College of Education and Behavioral Sciences, Addis Ababa University. Yekoyealm and Belay (2015) studied graduate student supervision in AAU with special reference to the perceived case of advisee-advisor credibility. Habtamu (2015) investigated challenges of PhD Dissertation Supervision at AAU: Education, Humanities, and Social Sciences in Focus. These studies, however, did not address the oral aspect of MA thesis examination.

In addition, to the best of the researcher's understanding, the discourse of teacher-student interaction in MA thesis oral examination sessionsin the context of Ethiopian higher academic institutions remains an unexplored territory. Globally also, researches related to the actual characteristics of teacher-student interaction in oral examination sessionsare limited to a small number of studies (Burling, 1997; Grimshaw, 1994). Thus, to partially contribute to the knowledge gap in the field, this study focuses on the interactive conditions that prevail in MAthesis oral examinationsessions which are conducted at the Department of English Language and
Literature, University of Gondar which is one of the first generation universities in Ethiopia. As far as the researcher'sassessment is concerned, no research study in this area is conducted locally, and nothing is known about this oral academiccommunication genre and the processes involved in the oral examination of MA thesis in Ethiopian higher academic institutions. Therefore, the study will shed light on how oral examination sessionsoffer theacademic discourse community useful information regarding the nature of teacher-student relations in such kind of academic communicative eventin Ethiopian higher academic institutions.

\section{RESEARCH QUESTIONS}

2.1 What does the power relation between teachers and students in MA thesis oral examination look like?

2.2 How does the power relation affect the practice of MA thesis oral examination and the postgraduate research?

2.3 how do teachers and students in MA thesis oral presentation sessions organize their talk in their interaction?

\section{THEORETICAL AND METHODOLOGICAL FRAMEWORK}

Fairclough's(1995) three-dimensional framework for discourse analysis is the theoretical as well as a methodological framework which sees discourse and discourse analysis as: a text (level of textual description), a discursive practice (level of interpretation) and, a social practice (level of explanation) exploring not only the text itself but also its production and interpretation within a larger social context. Any discursive "event" (i.e. any instance of discourse) is simultaneously a piece of text, an instance of discursive practice and an instance of social practice. 


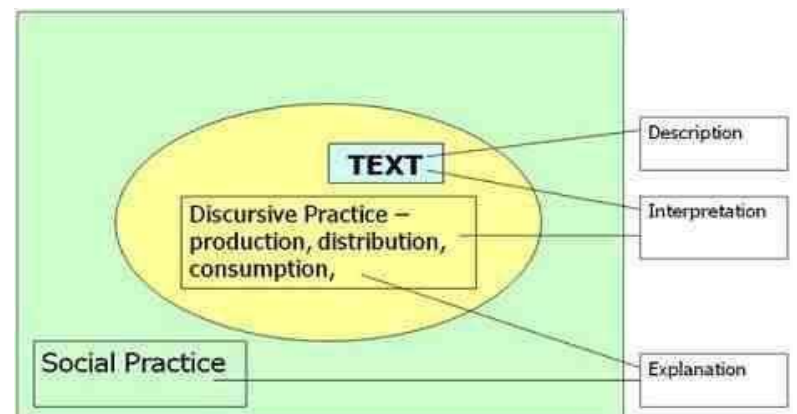

Figure 1: Fairclough's three-dimensional model for discourse analysis (Source: Fairclough 1995:98)

The text dimension is the language analysis of texts. Fairclough (1989: 106) also presented what he called a 'mini reference manual' in the form of a list of questions and sub-questions. The major divisions are as follows:

- What experiential values do words and grammatical features have?

- What relational values do words and grammatical features have? What expressive values do words and grammatical features have? What metaphors are used?

- What interactional conventions are used?

- What larger scale structures does the text have? How are (simple) sentences linked together?

Each of these questions has a set of subquestions. For example, the question "How are simple sentences linked together?" has a detail of questions as:

- What types of process and participant predominate?

- Is agency unclear?

- Are processes what they seem? Are nominalizations used?

- Are sentences active or passive? Are sentences positive or negative?

The discursive practice dimension involves processes of text production, distribution, and consumption whichspecifies the nature of the processes of text production and interpretation, for example, which types of discourse are drawn upon and how they are combined.

The social practice dimension deals with issues that are important for social analysis such as the institutional circumstances of the discursive event (i.e. the discourse of research presentation) and how that shapes the nature of the discursive practice and the constitutive effects of discourse (Fairclough, 2003:16). So the social theory of discourse can start to account for the relationships between texts, discursive practices and wider social and cultural dimensions, and thus can show how the production and reception of texts are ideologically shaped by relations of power.

\section{RESEARCH METHODOLOGY}

Teachers and MAstudents in the Department of English Language and Literature, UoGare participants of this study. Five MA thesis oral examination sessions were randomly selected, audio-recorded andtranscribed. Three instructors and three students were also interviewed regarding the nature of oral examinationsessions which is intended to validate the audio data. Finally, after major discourse themes were identified, analysis was made based on Fairclough's three-dimensional Critical Discourse Analysis Model.

\section{DATA ANALYSIS AND DISCUSSION}

\subsection{Analysis of Teacher-Student Power Relations}

The interpretation of asymmetry in discourse studies has been based on the unequal opportunities given to individuals and institutions to access resources (Fairclough, 1989, 1992; Van-Dijk, 1995). This situation is certainly found to be true in this study. In teacher-student interaction, the asymmetrical relation is manifested as a form of: teachers' alignment with the institutional authority, teachers as experts, and students' submission to teachers' authorities which are presented in the subsequent analyses as follows.

\subsubsection{Teachers' Alignment with Institutional Authority}

In this study, teachers were found to align with the institution's authority. This is evident in their comments with pronouns. They used them with the aim of giving credibility to: the performance of self 
through the use of the first-person singular $I$; the performance of self within the institution through the use of the first person plural we; and the performance of exclusion of the student through the use of pronoun you in subjective and objective forms (Fairclough, 1989). How teachers used them through their comments and questions is presented in the following extracts.

a) The use of the first person plural $W E$

\section{(Extract 1)}

No noleave it please. I am bored with what you are saying now.This is just to help you.Now,the problem is we teachers. The institution provides us great responsibility. Offering an MA qualification is great authority. At the same time, it is great responsibility. However, we could not compromise the two. This is what $\boldsymbol{I}$ always try to comment on. Anyway, if you have questions, you can ask.

(Taken from audio-recording 2)

The teacher's self-presentation through the institutional we invokes the academic authority through a linkage to a larger unspecified entity (Fairclough, 1989, 1992). The pronoun we is also used as a persuasive device through the institutional role of the teacher. The institutional power is baldly mentioned as a source of the teacher's power that the teacher is provided with the responsibility of evaluative decision on the student's work.The problem is we teachersaboveattributes it to a source that is beyond himwhich is also evident from the extract above theinstitution provides us great responsibility. The teacher asserts that he is responsible and authorized to offer MA degree to students. This can be understood as a power that adjusts the teacher's examining role with the institution, which gives him the power to assert his claims and convince the student to accept his comments.

Here, the teacher's use of the first-person plural wein we could not compromise the two sets the oral examination in the wider context of the university. Not the teacher alone, the teacher's alignment with the institution is responsible for the candidate's better performance, as was the case in the previous example. This implies that the collective authority of the institution strengthens the teacher's individual authority and that the two cannot really be differentiated. Of course, since the institution does not exist without teachers, it could be argued that the examining role is attributed with the institution.

In the following extract, the examiner shifts from weto $\boldsymbol{I}$ which is his examining role. Fowler and Kress (1979) suggest that power relations may been acted in the alternative use of personal pronouns, which are under scored by the different roles a person plays in a social context. The first person singular $I$, a $\sin I$ was in academic commission for a long time in the above extract seem store in force his role as, I, the examiner, has a long experience on the issue, so I am in a position to give you what you should do in your future work. Though it is a comment, which does not demand a response from the candidate, the fact that the candidate did not say anything about this speech act of self indicates his co-operation in this a symmetrical framework of teacher-student interaction.

(Extract 2)

T:... an academic agenda. So they follow the university's legislation. I was in Academic Commission for a long time. So most of the agenda was about student and teacher affairs. Nothing else except this. Now do you mean?

What does language use look like? Youknowitshouldn'tbewhatspeech actsaysthisandthatsomethinglikethat. (Taken from audio-recording 1)

(Extract 3)

$\mathrm{T}$ :

Don'tbefixed.YouradvisorsandIaskedthecoordinator.Itis betterto

callforameetingbecauseourstudentsreadvarietyofmaterial S

however,theystruggletotaketheirresearchestowardsthepo sitivist

paradigmbutthatisnotthecase.

(Taken from audio-recording 1)

The teacher'sutterance above also suggested that acall for a meeting regarding failure in postgraduate research isurgent andhehastheroletoinitiatethemeeting with theMA students' advisors whichisanaspectof maximizinghis credibility whichotherwisehasnorelationtothe agenda atissue.

Theterm"You"isanindefinite pronoun, whichhasarelationalvalueininteractionreferrin gpeople in general (Fairclough,1989:180).In MA 
thesis oral examinationsessions,teachers werefoundto use

pronounfrequentlytoaddresstheircommentsandcriticis mstostudents.

\section{(Extract 4)}

T: Comingtochaptertwo,fourpages! Four pages of review! Wawsurprising! Other papers rather the review is bigger. So much to review you know that in other papers, the review tends to be fifteen to twenty pages. So much! Four pages! What happened to you?

S: Youknowtheproblemis I confinedmuchof thestudiesdoneonthe

NileandIhavebeentoldby

my

advisortoconcentrateo

nstudiesontheNile

discourse.

T: You have fourpages of Literature which is too little.Because you don't have enough materials to start.

S: Yeah.

Sothisisashortcoming.

Somaybewhatconnecti onstheliteraturereview what peoplehavetalkedabout methodsdealingwithit. Becauseyourtableofco ntents,yourbibliograph yat theendisbig,alot!

(Taken from audio-recording 1)

Itisevidentintheuniversitylegislation thatPhDcandidatesconducttheirresearchesunderthe supervisionoftheiradvisors(UoGLegislation,2015).Advi sorsare alsoresponsibleto advisetheirstudentsandconfirmfortheirthesiswhentheirw orksare matureenoughfordefense. Accordingly, the thesisisnotonlythecandidate'sownw or k

butalsotheworkoftheadvisor.Thisbeingthe case, therepetitiveuseofthepronounyou showsthatitisonlythest udentwhotookallthe responsibilitiestotheworkasclearlydepictedfromtheteach ers'commentsandcriticismsin the extractabove.

Theaboveextractshowsthatthecandidatepresentedhispil otreportwithareviewsectionoffour

pages.Thesizeofthissectionclearlyshowsa

shortcominginthecandidate'sreportthatthereisa

departmentalconvention, whichlimitsthesizeofareviews

ectionforan M A thesis.The teacherinhis utteranceshowedhissurpriseforthe deficiencywith hyperbolictoneas in the extract fourpages! towhich the teacheraddedinhiscommentthattheaveragesizeofthepap erhadtobefifteen to twentypages. Waw!(Signof greatsurprise)Four pages!What happen to you?(Withgreatsurprise).Inthe examiners'turnsabove, however,thecommentsimply anexclusionof the studentandinclusionofthestudent'sadvisorwhoisalso responsibleforthe quality of the thesis. Thisindirectlyimpliesthatteachersclaima commongroundwith advisor-shipidentityor they include theadvisorshiprolewhereastheyexcludetheroleof studentshipwhichmayimplypolarizationtowardstheinstitutiona lrole.

\section{(Extract 5)}

$\mathrm{T}$ :

Wewillcometothedetailslater.Youhavesomegeneralques tions.

Youwillcometothedetail.

$$
\text { S: Uhhhm }
$$

$\mathrm{T}$ :

saidthathewascorrectbuttold

Letmegivehimoneexample.He himthathewasnotcorrectandheshoulddoitcorrectly.Ifheg oesonthis

$$
\begin{aligned}
& \text { way,hewillnevergetan } \\
& \text { degreebecause } \\
& \text { Iamsure,itisthewrongmethodology. }
\end{aligned}
$$

S: Ok. What I did on the methodology...

T: Haveyoufinished?

S: Ok, you can goahead.

(Taken from audio-recording 2)

Intheextractabove, theteacher'sperformativeutteranceIf heproceedsinthisway, hewillnever claiman MAcan be interpretedasaninfelicitouscomissivespeechactwhichco uld ratherbe mitigatedas,Ifyouproceedin thisway, itwillseriouslyaffectyourfinalwork. Austin (1962:39)labeledsuchtypeof speechactas"anaction, whichisperformedwithoutexpect 
edthoughtsor

feelingsmotivatedby

abuses.”Anabuseisaninfelicitousperformativeutterance thatiscommitted

intentionally. Theintentionoftheteacherseemsjusttoexer cisehispoweroverthecandidateasif

heistheonlyonewhohasthemandatetoofferan

MAdegreetothestudentwhileitisonlythe

academicinstitution, whichis

in chargeofexecutingsucha

duty.Thoughtherearemethodological problems in the student's report, in the teacher's final remark, I am sure, it is the wrong methodology,Iamsureimpliesthatthereisonegeneralrule andoneconventionalway

ofdevelopingamethodologyindoingresearchandtheteac herisincontrolofthatconvention.

Sinceknowledgeisdistributedornotpossessedbyindividu als, theteachercouldhave left aroom to the candidate's experience taming his comment, which could be paraphrased as, "in my opinion, as far as I am concerned, etc." (Brown and Levinson, 1987).

\section{(Extract 6 from Interview)}

Yeah, some teachers could be unnecessarily you know unfairly angry at students and may abuse for some reasons and at this time the student becomes offended.

(Taken from teacher interview 1)

In the previous extract above, the teacher's utterancehe will never get an MA degree because I am sure, it is the wrong methodology can be understood as an intimidating discursive act that the teacher used to get the candidate readily accept his views. The teacher's comment taken from the interview data above is a confirmation to how teachers in thesis oral examination sessionsabuse their power aligning their examiner role with the institutional authority.

\subsubsection{Examiners as Experts}

Teachers in MA thesis oral examination sessionswere found powerful figures who claim to have complete control of the resources of research knowledge who werepositioning MA students as mere recipients of their knowledge claims, that is evident in the subsequent analyses below.

\section{(Extract 7)}

T: Generally,I cangiveyouthewholeof theideasheretobe Included. The first one is the societal background.

(Taken from audio recording 2)

(Extract 8)

$\mathrm{T}$ :

Well,I

donotknow.Itisnotwellagoodyouknowreportatall.

Evenyouarenotawareaboutthetableofcontents.Thisisw ritingfor

thesakeofwritingyeah.

(Taken from audio recording 2)

Inthe extractsabove, the teacherappearsan expert whohas a complete control oftheknowledgeof academicresearch.He, in his utterance used...Generally, whichis anadverb thatpresupposeswhathewas commentingsofarwasacceptablewithoutfurtherargume ntisneeded.Theteacher'smodalchoice caninIcangiveyou accordingtoHalliday(1970)isahighv aluemodalauxiliaryverbwhichshows theexaminer'scertaintyofknowledge claimaboutthewholeresearchissuesthatthe student is expected toincludeinthebackgroundofthestudy.Fromthe researcher'sobservationofMA thesis oral examination,teachers'perspectives regardingideasthatshouldbeincludedinaresearchbackgr ounddifferwidely. T he t e a c her's suggestion Icangiveyouthe wholeoftheideasin the above extractclearly demonstratesthattheteacheris the onewhomonopolizedthe knowledgeof research, whichis a kindof departurefromthenormativeoral examination, whichdoesnot totallyleavelittleroomto thestudent'sresearchexperience.

Theteacher'sutteranceItisnotagoodyouknowreportatall. Evenyouarenotawareaboutthetableofcontents. Thisisw ritingforthesakeofwritingyeah alsocriticizedthatthework isirrelevantandpoorlyratedthat hecouldnotmention tolabel. $\mathrm{H}$ i s u t t e r a n c e Well,Idon'tknow intensifiestheweakness which is followedby aseriesofcriticismsthatdownplaysthequalityofthestudent 's work. Thestudent seems a powerless participant of talk who is leftdoomed anddiscursivelyhelpless, whichmay be seen as a forecastof badfortunetotheratingofhiswork.Mostof the teacher's comments I don't know, It is not well a good you know report at all, Even you are not 
awareare negatively marked. The repetitive use of the negation implies a valuation of the teacher's expertise by devaluating the student's performance; in this case, the teacher magnifies his superiority on the student's expense through egotism (Swales, 2004:163).

\subsubsection{Candidates' Subordinating to Examiners' Authority}

The students'submissive acttoteachers'authorityisoneofthethemeswhichwasiden tifiedasone way ofrevealingthenatureof powerrelationspersistingthroughoutteacher-

studentinteractionin MAthesis oral examination sessions. Thepowerrelationismanifestednotonlybythete achers'control

ofthestudents'freedomofactionbutalsowhenthestudents behaveinasubordinatefashionat the same time through compliance to the teachers' questions and commands, which are the directive speech acts that gave teachers the right to control teacher-student interaction, but forced students to comply in accordance with their subordinaterelation to teachers (Fairclogh, 1989:46).

One feature of MA students' act of submissiveness is acceptance of control. MA students were receiving the massive information given to them with no question trying to carry out the wishes and wants of examiners whether these be directly expressed through imperatives or indirectly as declarative forms as presented below.

\section{(Extract 9)}

$\mathrm{T}$ : ... so what does it talk about? Discourse analysis.

S: Discourse, DA, discourse analysis as a method and theory.

$\mathrm{T}$ : Let me tell you as a method and [a theory?

S: [a theory.

T: [which one did you take? As a method or as a theory?

S: [It can be used because I used discourse analysis] as a method and theory.

It is possible.

T: Both?

$\mathrm{S}$ : Yes, It is possible to use discourse analysis both as a method and a theory.

$\mathrm{T}$ : Ok, now, where is the theory aspect?

S: Theoretical framework.
T1: Theoretical framework doesn't mean that. It is not discourse analysis. It is not discourse analysis.

T2: Ok. So what?

S: Ummm

T: So please, if you accept... [time, place...

S: [No, I am ready to accept. I will accept. It is valid information. I will accept, ok.

(Taken from audio recording 1)

In the first line of the extract shown above, the teacher asks the student to know what issues the section discourse analysis in the thesis is dealing with. As clearly indicated in the student's answer, discourse in this particular research is used as a theory, as well as, a method. The teacher echoing the student's response trying to show that discourse analysis couldn't be selected as a method and as a theory at the same time which is evident in his utterance let me tell younow as a method and [a theory? Andwhich one did you take? As a method, or as a theory? The student's claim appears quitelogical that discourse analysis could be used as both a theory and a method which is evident in many books written in relation to discourse analysis such as Gee's (2011) as the student mentioned in his previous responses. The studentin his response seems consistent that discourse analysis could be both a theory and a method. As can be seen in the extract that theteacher forced the student to simply accept or comply with his wishes and wants. The student then accepts naively the whole issue what the teacher imposed without hesitation. The implication of the teacher's utterance So please, if you accept...can be understood as a precondition which obliges the student to readily accept his views which otherwise may have a negative consequence. The student's response No, I will accept, accept. It is quite important evidence. Ok. Also suggests a kind of submissiveness to the teacher's self-evident authoritative power that can be understood as quick withdrawal from the debate by taking greater care of addressing the face wants of the teacher which seems the student's intention of seeking the teacher's fairness in the evaluation of the student's work. Morand (2000) cited Dahl (1957) contends that subordinates are careful not to offend or infringe on those upon whom they are dependent; power relation by definition implies dependency.

(Extract 10) 
T: Isthatdiscourse?This is ratherprocedure.

S: Didn't I[tryto...?]

$\mathrm{T}$ : [>Nonono]wait waitwait<. This is to help you learn from the comments. You are so nervous. Wait wait!

S: I,I ameagertolearn.I

ameagertolearn.I

ameagertolearnbecause

instructors. you are senior

T: [Nono.] please leave it. I am bored with this.

(Taken from audio recording 1)

\section{(Extract 11)}

T1: Thechairpersondidn'tdothis.

Isthatdiscourse? Is ita procedure?

S: Didn't I[tryto...?]

T1:

[>Nonono<]waitwaitwait.Tolearn,don'tb elikethis,wait,wait.

T2: I,I ameagertolearn.I ameagertolearn.I ameagertolearnbecause youareseniorinstructors.

T1:[Nono.]

$\mathrm{T} 2$ :

[Nono]Notthis,leaveitIamboredwiththis.T hisistohelpyou.

(Taken from audio recording 1)

In the above extract also, the students's utterance Did not I[try to... shows that he is in need of being free from the teacher's criticism. The utterances of the teacherIs that discourse?Is it a procedure? are invoking to a positive feedback of praise which is instead rejected by the teacher, and interrupted with a rushing intrusion in to his psychological territories > No no no<followed by a comment on the student's appeal to the teacher's authority. As Morand (2000) cited Dahl (1957) claims, in the extract shown above, the praise in most occasions comes from the studentto the teacher as in the utteranceI, I am eager to learn. I am eager to learn. I am eager to learn because you are senior instructorsthough it is rejected and held in contempt by the teacher when he baldly said, I am bored with such sort of thingswhich is evident in the above extract.

\section{(Extract 12)}

$\mathrm{T}$ : different. Teacher education, it is definitely teacher training ok? It isequivalent to teacher training. Teacher well, teacher education or

teacher training meaning that it is the field of study...

S: Is that? Is that?

T: Pardon.

(Taken from audio recording 2)

It is possible to understand from the above extract that the teacher in his utterance distorted the definition of "Teacher training". Nevertheless, the student attempted to comment the examiner for his wrong definition; rather he showed a hesitation Is that? Is that? a strategy of restricting his freedom as if he was not sure of it though he clearly knew the teacher's definition was wrong which was later confirmed by the teacher himself in his utterance Pardon. Mulholland (1995) asserts that speakers hedge or speak hesitatingly in order to indicate that the act being performed is not intended to impose on the hearer or to restrict his or her freedom.

\section{(Extract13)}

$\mathrm{T}$ :

...WhatdoyoumeanbyabletouseEnglish?Yeah,yeah

S: Yeah,canI,canIreact?

$\mathrm{T}:$

[Failure,shortage,shortageoftimeandforCPDsucces s,indicators

ofsuccess, pairinggroupingstudents. Thatisyouknow indicatorof

success.

(Taken from audio recording 2)

Thes $\mathrm{t} u \mathrm{~d}$ e $\mathrm{nt} \mathrm{s}$ ' a c t

o f subordinatingtot e a c h e r s 'authorities inMA thesis oral examination sessions wasalsoevidentthroughthe

students'diffidentbehaviorasseen

inmostofthestudents'responses. Theaboveextractshows that theteacherposedaquestionexpectingthestudentto makeclearwhathe meantby abletouse English. While theteacher's question demands the student's answer, which is $\quad$ its commonadjacencypair(Schegloff,1979:210), thestuden t'squestionYeah,canI,canI react?isa kindofrequestthatshowshissycophancy.Linell(1990:15 
9)pointsoutthat"asking questionsisawellknowndominantstrategyunlessquestionsthatshowsubm issivenessoftenby a subordinateoneintendedtoshowdeferenceandrespect".

\section{(Extract14)}

T:Yeah,doitthatway.Doitthatway.CPDtrainers'intervi ew,trainers'

interview,ok?

S: [And...

$\mathrm{T}$ : [What about the questionnaire there?

$\mathrm{S}$ : The questionnaire [is...

$\mathrm{T}$ : [What is the questionnaire there?

$\mathrm{S}$ : The questionnaire is meant for [English language...

T: [No, no I am not saying any other thing.

S: [English ahm ...

$\mathrm{T}$ :[Whatisthequestionnaire?Isi tstudents'questionnaire?Teach ers'questionnaire? (Taken from audio recording 1)

Theaboveextractalsoshowsthat,inallcasesofthestudent' sresponses, theteachersimply passesintohis nextquestionwithoutregarding whatthestudent

hassaid;theteacheralso

interruptedthestudent'sresponse,or

cutitshortwithsomedismissiveremarkthoughoral examinationrequires patient questioning so does it also necessitate good listening (Pearce, 2005: 91). The teacher'sinterruptionsaretaken-for-grantedby

thestudent. Whentheteacherinterrupts, the studentfailstopursuehisspeechandadjustshimselftothe teacher'sdiscursivelysequenced interruptionsaccordingtoFairclough(1989:137;2003,47 ), a denialofaccesstointeractionvoluntarily withoutany resistanceto the teacher'sdisruptions.Scott(2006:130)describes:

thosepowerless participantsof talkaresubordinatingtothe powerfulfor differentreasonssuchas: fearof punishment (fear psychicor sanction punishment), self-interest that emanates from prestige, relative power position,lackofself-

confidenceandsoforth.Fromtheanalysessofar,it is possible to conclude that MA studentsthusseemtosharethereasonssuggestedbyScotta bovetotheirsubmissivenesstoteachers'dominance.

Studentswerealsointerviewedtoreflect ontheinteractionalproblemsthey faceduringMA thesis oral examinationsessions. They pointedout a variety of reasons contributed to their submissivenesstoexaminers'power and dominance. Below isthedatataken from astudent's interview:

\section{(Extract15)}

Ok,yeah,bothdohaveideologiesIthink.

Theexamineecomeswithacertain ideologyabouttheexaminerasIhavesaid.Ca ndidatesalwaysaskotherpeople

whohavebeenexaminedby

theexaminerstowhomthecandidateis

assigned.They alwaysask howhe acts and he

evaluates.Basically,peopleshouldnotasksu ch

questionsbecausethequestionsheforwardsa nd thecommentshemakesshoulddependon the work that examinee has produced. So they are always related to other factors.

\section{(Taken from student's interview 1)}

As can be seen in the student's response above, teachers and students have their own preconceived notions about each other's behavior. Students try to collect information from seniors about the behavior of their teachers in advance of the conduct of oral examinations. This will help them to know how to act in oral examination sessions and adjust themselves to the way their teachers act during oral examination. This apparently shows that when students tend to use submissiveness as an interactive strategy, they can easily get teachers' credence and can easily pass through and stay in a safe situation.

\section{(Extract16)}

...soanywaythereisakindofpower difference.Teachersarealwaysthe ones whohaveto put theirheadsdownnotfor showingrespectofcoursebut to showthatteachers arealwaysall knowing andwhateverthe questions teachersask, thestudentmaynotbeinapositionto defend.Ifthestudentdefends, hema ythinkthat itmayresultinunnecessaryorunexp ectedconsequences.Sohehastoalw aysaccept thembutteachersaskquestionsand 
studentstry to answer butdo notchallenge.

(Taken from student's interview 3)

Thestudentintheaboveextractfurtherstatesthatthe students' subordinationtoteachers' authorityisalsomotivatedbyrespectingteachers'p owerthroughcompliances becausetrying to argue with teachers is considered negatively as "defensive" behavior which is seriously condemned

byteachersasinthefollowingextracttakenfromthe interview.

\section{(Extract17) \\ Astudentshouldcomeopen- mindedsothathe/shecantakecom ments,he/shecanget feedbacks.So,onehastobeopen- minded.Onehastobereadytolearn from theprocessfromtheinteraction.Im eantheydonothavetobedefensive .They donothavetoreallytrytodefendth eirwork. \\ (Taken from teacher's interview 3)}

\section{Thereisa}

contradictionbetweentheuseoftheterm"defensive"inthe teacher'scommentaboveand thenamegiventothis academiceventthatis"Thesisdefense" or "thesis oral examination".Whilethepurposeofconducting such academicsessions istocreate opportunities forstudentstokeeptheir positionbyresponding toteachers'questions, defensiveisperceivedbyteachersn egativelyasanobstinatebehaviorwhich canbeunderstoodasamotivefor makingstudentssubmissivetoteachers'dominance.

\subsection{Analysis of Interruptive Speeches}

Theanalysis ofinterruptive speeches willprovideusanswerfor the questionhowteachers andstudentsin MA thesis oral examinationsessions organize their talk in their interaction. Before conductingtheanalysis,criteriawereset which is adapted from West and Zimmerman (1983) todecidewhatconstitutesinterruptivespeechinthecontex

$\mathrm{t}$ ofteacher-studentinteractioninoral examination sessions. Thesubsequentextractsanalyzedin theforthcomingsectionsdepictedthatteachersandstuden ts usedinterruptionsfor differentintentions. Teachersusedinterruptionstostopstu dentsfromgiving "irrelevant"information, toensure studentsgivethekeyinformationteachersexpected of them. Interruption as one dimension of power relation between teacher and student is discussed with subsequent extracts below.

\section{(Extract18)}

$\mathrm{T}$ :

Well,itisjustwritteninthatmanner.Ok,uhmclassroomo bservation,ok?

Whatdoesitmeaninterviewthere?

S: Inter [view...

T : $[>$ No, no, no $<\mathrm{I}$ amsayingitsaysyouknow[therearesomanyinterviews. S: [Yeah,yeah.

T:

Animalsinterview, plantsinterview, whatdoesthatmea $\mathrm{n}$ ?

S: Well,itsayssomewhereininin[the...

$\mathrm{T}$ :

$[$ No,I

don'tjustputitsomewhere. Whydon't

youjustgivemeastraightforwardansweryeah?

S: I interviewedCPDtrainees.

$\mathrm{T}$ : Shallwesayittrainers'interview?

S: CPDtraineryeah.

$\mathrm{T}$ : Yeah,doitthatway.Doitthatway.

(Taken from Audio recording 3)

Intheextractabove, theteacherfrequentlyinterruptedthe candidate.In allcases, thecandidate's responsesarefailedattempts. Asclearlyseenin the teacher's

utteranceWhatdoesitmeaninterviewthere? theteacherpo sedthe

question withtheintentionoflettingthestudentmakeclea $\mathrm{r}$ thegroup towhomtheinterviewissetas he mentionedin the methodologysectionof histhesis. WhilethestudentwastryingtorespondtothequestionInter [view...,theteacherquickly interruptsthe student nullifyinghisresponseas ifitwasirrelevantandnonexistentwithout giving dueattentiontowhatthe responsemightbe. Theinterruptionatthe thirdsyllableoftheword

Inter[view..., andtherepetitiveuseofthenegationa $\sin N o$, no,noIamsayingitsaysyouknow demonstratesthe teacher'swrongassumptionthatthestudentmay not beableto comeas intendedby theteacher.Inhisattempttointerrupttheteacheryeah,yeah,t 
hestudent gavea confirmationtotheteacher'sassertiontherearesomanyinte rviewstherebecausethemaingoalofthespeaker'sassertion (theteacherinthiscase)istohavehisviewaccepted without discussion or question (Mulholland, 1995: 165). The teacher'sinterruption of the student's preceding contributions introduced a new but the same question accompanied with utterancesthatarediminishingtheworkofthe student, whichisevidentinhisutteranceabove Animals interview,plantsinterview, whatdoesthatmean? that hasnorelationwiththe purposeofthe oral examination. Therefore, itis possible to conclude that teachers have the right to control the productionofthediscourse of MA thesis oral examination sessions, which wasalsoconfirmedbytheinterviewmade with a student participant.

\section{(Extract19)}

No, no, no.By theway,youseea unidirectionalsession.Examinersdohavet imesor roomstosay as muchtheywantas muchthey need.Letalonethe attendants, the presenterortheexamineeisallowedtosaya sentenceortwosentences.Notmore thanthat.Letalonetheattendantswhosimp lystaythereuptotheend ofthe session. Simplyobservingandlisteningtowhatwas saidbythebossesyouseebettertosay.

(Taken from student's Interview 2)

The extractabove further illustrates that teachers are in a position to control the floor and monopolizethe discoursespacethatstudentsneedto share.CollinsandGuetzkow(1964)argue thatmonopolizingthefloorisa moreimportantmeansofachievingdominance.Theinterv iewfurther indicatesthatoral examinationsessionsareunidirectionalthatteachersarein a privilegedpositionto exercise theirpowerover students. Inprinciple, $\mathrm{e}$ a $\mathrm{ch}$ e r s are required to create conducive environmentsforstudentstogetthemfreely involvedintheinteractionthanto brush off their contributionsthroughfrequentinterruptions.

\section{(Extract 20)}

T:...ifyoulookat

theindicatorscolon,ELIP,theaimthemaj

oraimofELIPwas
tohelptoimproveEnglishteachers.Indicat

orsforsuccessorfailurefor success, theindicator wasthatabletouseEn glishandfailure, short ageoftime thatisnotclear.Whatd oyoumeanbyabletou seEnglish,yeah,yeah

S: [Yeah, can I, can I react?

$\mathrm{T}$ :[Failure, shortage, shortageoftimeandforCP Dsuccess,indicators ofsuccess,ahhhpairin ggroupingstudents. T hatisyouknowindicat orof success.So whenteachersareable toformgroupsandyou knowmake studentsworkinpairs, S: [Yeah,yeah.

$\mathrm{T}$ : Animalsinterview, plantsinterview, whatdoesthat mean?

S: Well,itsayssomewherein[the...

$$
\begin{aligned}
& \text { doesthatmeantheyar } \\
& \text { esuccessfulinteachin } \\
& \mathrm{g} \text { and failure to } \\
& \text { teaching peer work? } \\
& \text { That part is not } \\
& \text { clear. }
\end{aligned}
$$

S: Shall I?

T: Yeah.

$\mathrm{S}$ : Ok, in the first case, in the case of ELIP, I was, I was a trainee and a trainer

(Taken from Audio-recording 1)

Intheexemplarabove, theteacherreadalistofvariablesthat werenotclearforhiminhispre- presentationreadingofthe student'sthesis, and askeda questionWhatdoyoumeanby abletouse English?a kind of speech actwhichnormallyseeksananswerfromthe student.Thestudentaskeda counterquestiontogettheteacher'sapprovalandclarify hispoints.However,the teacher ignoredthe studentand continued his questioning repeatedly reading the variablesaccompaniedwithlongervocalfillersahh $\boldsymbol{h}$ which 
depictedthediscomforthe

feltin

readingthestudent'swork. Thestudent'sfailedattempttoge thefloorimpliesthatthe

teachercouldlimitthestudent'scontributionfromgettingan accesstothe interaction, whichmay

givehimthechancetoreflectonthequestionposedby theteacher.However,inhissecondattempt, thestudentcouldgetthechancetoreflecton hisviews. Thiscanbe understoodasandreflectedthat research oral examination sessionsdo notseemto be setforextendeddevelopmentof

argumentsfortherevelationofthe student'strueself.

\section{(Extract 21)}

T:Canyou justtell methetoolsthe tools that you have? You haveclassroom observation, interview, andthe questionnaire

S:Yeah.

T: Well,itisjustwritten in that manner. Ok,uhmclassroom observation,ok? What does it mean interview there?

S:Inter [view...

$\mathrm{T}$ :

$\mathrm{T}:$

Why don't

youjust give meastraight forward answer,yeah?

S: I interviewed CPD trainees.

T: Shallwesayittrainers'interview?

S: CPDtrainer yeah.

T: Yeah, doitthatway. Doit thatway.CPDtrainers'interview, trainers'

interview, ok?

S: [And...

$\mathrm{T}$ : [What aboutthe questionnaire there?

$\mathrm{S}$ : The questionnaire [is...

$\mathrm{T}$ :

[Whatisthe questionnaire there?

$\mathrm{S}$ : The questionnaireis meant for [English language...

$\mathrm{T}$ :

[No, noI am not

saying any other thing.

S: English [ahm...

T: [Whatisthe questionnaire? Is itstudents' questionnaire? Teachers'

questionnaire?

S: No, Englishlanguage teachers.
(Taken from audio-recording 1)

Oneeasily visiblefeature which ismarked bythesquare brackets in the above extractisthenumber of times the teacherinterruptsthe studentin. Theteacherinterrupted the

studentandcontrolledhiscontributions. Theteacher'sint erruptionbeganwhenthe

studentisstartingtorespondtohisquestiontryingtomakec

learwhathemeant byinterviewinhiswork. The teacher'sinterruptioninthethirdsyllableofthewordInter [view...therepetitionofthenegation

[>No,no,no<canbe understoodasrefusaltothestudent's completeresponse.Theteacherthen paraphrased hisquestioni n toastatementwiththeintentionofmakingh is question cleartothestudent. Thoughthestudent'sresponseYeah,y eahshowsthatheisclearwith the intentionofthequestion, theteacherstillcontinuedasking a questionaccompaniedwitha comment A n i m a ls interview,plantsinterview, whatdoesthatm ean?whichmay haveathreatening effect onthestudent's facewants(Fairclough,1989:46).

Thepowerrelationshipbetweentheteacherandthestudenti salsoexpressedwhenthestudent

isrepeatingtheprepositioninthreetimes in his utteranceWell,itsayssomewhereininin

[the...andlosehisway

asaresultoftheteacher'sinterruptionwhich

showshisconfusiontothinkandgo

forwardclearly.Thus, thestudent'sutterancesomewhere $\mathrm{i}$ mplies,I donotreally knowtheexactplace wherethe pointis locatedin histhesis.Thisfurtherexposedthestudenttothe moreoutrageous comment, whichmayevokesillinessonthestudent'sface.In the same

ve in, thestudenttriestogiveacompleteanswerforthequest ionsposedintheprecedingturns but his attempt is made aborted by the teacher's question What about the questionnaire there?The teacher'sinterruptivespeechesarefrequentlyunderscored bynegationandputthestudentinapositionoffacingfrequent challengesofperusinghisspeechtoreflecton

hisviews.Referringbacktoteacher-

studentinteractionintheirprecedingexchanges, mostof the interruptionsin the above extract aretendtoclusterwhenthestudent'sresponsesarenotmeani ngful as expectedbytheteacher.

(Extract 22) 


\author{
Yeah, I think it is a coward \\ situation that means in most cases \\ examiners \\ are \\ dominant.Theydominatethe \\ candidateevenwhenthe \\ candidatestarts to outshineand \\ narratehisfeelingstheytry to \\ interfere,trytopauseandthereisakind \\ ofunequal powerrelationandthis \\ isseenas domination.They \\ thereforereflecttheirauthority \\ duringdefense. \\ (Taken from student's interview 2)
}

Thetextual quoteabovealso illustratesthatthe situationinoral examinationsregardingteacherstudentinteractionlooksintimidatingtostudentsduetothe dominanceteachers have overtheoral examination discoursethrough interfering,andstoppingthe studentsandreflecting their viewswhichdepicts theirauthoritativepower.

(Extract23)

$$
\begin{aligned}
& \text { Well,whethertherewasafriendlyamorefrien } \\
& \text { dlyinteractionbetweenthetwoor } \\
& \text { not,thereisstillinteraction. } \\
& \text { Therearestillopinionsthataregivenright?Th } \\
& \text { isopinionwillbehelpful. } \\
& \text { (Taken from teacher's interview 1) }
\end{aligned}
$$

In the above interview made with the teacher also asserts that teachers are found to be speakers than listeners whose opinions seem to be readily acceptable. Theteacher's comments from his utterances abovemightbeinterpretedast $\mathrm{h}$ at

thereisaninteractionbetweenteachers andstudents, andteachersgivetheir opinionswhich arehelpful tostudents. However, the expressionwhetherornotshowsthereisstillinteraction, $b$ uthetriestohide

whetherandwhattypeofinteractionexistsbetweenteache rsandstudents. Fromthisandfrom theanalysessofar,onecanarguethatmuchofthediscourses paceinteacher-studentinteraction in MA thesis oral examinationsessionsisunderthecontrolofexaminers.

\section{CONCLUSION}

Inthis study, attempt has been madeto examinethepowerrelations betweenteachers and students in the context of MA thesis oral examination in the Department of English Language and Literature,
University of Gondar. Insodoing, the majorthemes(a) Teachers'alignmentto

institutionalauthority,(b)Teachers'as experts, (c) MAstudents' subordination to institutional authority, and (d) teachers' and students' interruptive speecheswere identified and criticallyanalyzed.Theanalysesthusdepictedthatteacher swerefoundtoexercise theirpersonal power to show their expertise as well as their institutional power through aligning themselves with the institutional authority. Students, on the other side, displayed consent and cooperation with submission to teachers' authorities.

Aligning with institutional authority is one of the themes that are identified in this research. In MA thesis oral examination sessions, pronoun choice is found a powerful discursive technique through which the examining role is enacted in teacher-student interaction. The most frequently used pronouns include: first-person singular $\boldsymbol{I}$; first person plural we; and pronoun you in subjective and objective forms (Fairclough, 1989).Teachers use the institutional we for variety of purposes such as: to display the production framework of talk or a footing in which the speaker only speaks on behalf of the authoritative source to connect with the power of the institution, to invoke a larger authority to legitimize their institutional power that helps them to freely control the discourse. Teachers also interchangeably use we and $\boldsymbol{I}$ to strengthen their institutional power with the power of their examiningrole, which means, the relations teachers have with students were also enacted through the alternative use of personal pronouns. Teachers also use pronoun you to address the problems in the oral examination to the students. It was also found that the teachers' frequent use of the pronoun you was an indicative of exclusion of the candidacy role, which is one of the teachers' roles in higher academic institutions.

Teachers' lackof consideration to students' research experiences and controlling of the discourse of oral examination sessions is one of the manifestations of teachers constructing of their power relations with students. Teachers in these sessions found to be powerful figures who claim to have complete control of the resources of research knowledge positioning students as mere recipients of their knowledge claims. Teachers valuing their expertise power by devaluating of the students' 
presentations, on their expense through egotism (Swales, 2004:163). This contradicts with the assumptions the conduct of such sessions are built up on. Rorty (1979) regarding this states that knowledge as a cultural product, constructed by the practices of the discourse community through interaction (academics involved in oral examination sessions) and constituted not just conveyed.

The analysis further revealed that while teachers were committed to the truth value of propositions in their claims, students showed expressions of lack of commitment to the truth value of their propositions due to lack of confidence in reflecting issues in their research. Their modal choice was also associated with the subordinate position they have in presentation sessions. Teachers and

students were also found to show their commitments towards their propositions in different degrees. Their modal choice put them in different positions. While teachers frequently used high value modals that show a strong commitment, students used low value modals, which imply a weak commitment to their propositions. So it is possible to infer that oral examination sessions are academic rituals where teachers predominantly control the knowledge claim of academic research.

Students also found subordinate to teachers as a strategy of gettingcredence in order to secure a positive evaluation of teachers. They used such strategies as: quick withdrawal from the debate, showing dependency on teachers through obedience to their dos and don'ts, pretending to take greater care to the face wants of teachers, through appeal to pity, and servility through praising insincerely.

Interruptive speech is one of the themes that were examined to see how teachers and students organized their talk in their interaction. The analyses depicted that majority of the interruptions were made by teachers. Teachers' interruptions were mainly aimed at stopping students from giving "irrelevant" information, and asking students to give the key information expected by them. The analyses also indicated that teachers' interruptions were discursive tools that gave them to control the oral examination discourse to freely ask questions and give comments. The analysis so far also made clear that the teachers' interruptions were successful in controlling the discourse of such academic events. Though interruption may sometimes signal involvement rather than power and dominance, the teachers' interruptions however were likely to be related to power and dominance to get their points accepted. Based on this, it seems being logical to conclude that teachers have the right to interrupt candidates with their comments and questions.

Unlike teachers, students on the other hand made interruptions very rarely not to oppose and make counter arguments, not to ask questions and illicit information from examiners but to give confirmations to teachers' assertions, as well, to get examiners' approval and clarify their points. It was also found that students comply and answer in accordance with their subordinate relation toteachers. From this, it is possible to conclude that teachers are powerful participants who were able to treat interactional conventions in a more cavalier way, as well as to allow or disallow varying degrees of latitude to the powerless participants (MA students). This implies that in MA thesis oral examination sessions, teachers are licensed to interrupt students; whereas, students are working under the interactive conditions that are framed by teachers. In general, the greater the inequality between teachers and students, the more likely it is that their interruptive speeches will be nonreciprocal, that is teachers as powerful participants have the right to interrupt students at any time and any place without showing apology, which is not totally allowed to students to do.To conclude, teacherstudent power relations in MA thesis oral examination sessions have been found to have an implicationto the poor quality of the students' theses work.

\section{REFERENCES}

Austin, J. (1962). How to do things with words. Clarendon: Oxford.

Brown,P.and

Levinson,S.(1987).Politeness:Someuniversalsinlangu ageusage.Cambridge:CambridgeUniversityPress.

Burling, R.

(1997).TheNorwegiandisputas.Antropolognytt,2,8-21. Collins, B.andGuetzkow, H.(1964). Asocial Psychology ofgroup processesfordecision making.NewYork:Wiley.

Fairclough,N.(1989).Languageandpower.London:Routledg e. 
Fairclough,N.(1992).Discourseandsocialchange.Cambridge :PolityPress.

Fairclough, N. (1995). Critical discourseanalysis: The criticalstudyoflanguage. London: Longman.

Fairclough,N.(2003).Analyzingdiscourse:Textualanaly sisforsocialresearch.LondonandNewYork:Rutle dge.

Fowler,R.,Hodge,R.,Kress,G.andTrew,T.(1979).Langu ageandcontrol.London:Routledge.

Gee, J. (2011). Introduction to discourse analysis: Theory and method (3rd Ed.). New York: Rutledge.

Grimshaw,A.D.(1989).Collegialdiscourse:Professiona lconversationamongpeers. Norwood, NJ:Albex.

HabtamuW. (2005). Challenges of $\mathrm{PhD}$ dissertation supervision at AAU: Education, Humanities, andSocialSciencesinfocus.AddisA babaUniversity.Inpress.

Halliday,M.A.K.(1970).Functionaldiversityinlangu ageasseenfromaconsiderationof moodandmodalityinEnglish. FoundationsofLanguage, 4,225-42.

Hartley, J. (2000). Nineteen ways to have a viva. Quarterly Newsletter, 35, 22-28.

Linell, P. (1990). The power of dialogue dynamics. In I. Marková\& K. Foppa, (Eds.), the dynamics of dialogue, 147-177. London: Harvester Wheatsheaf.

Morand, D. (2000). Language and power: An empirical analysis of linguistic strategies used in superior-subordinate communication. Journal of Organizational Behavior, 21, 235-248.

Mulholland, J. (1995). The language of negotiation: a handbook of practical strategies for improving communication. London and New York: Routledge.

Pearce, L. (2005). How to examine a thesis. New York: Society for Research into Higher Education \& Open University Press.

Rorty, R. (1979). Philosophy and the mirror of nature. Princeton: Princeton University Press.

Schegloff, E. A. (1979). Identification and recognition in telephone conversation openings. In G. Psathas (Ed.). Everyday language: Studies in ethnomethodology. New York: irvington.

Scott, J. (Ed.). (2006). Sociology: The key concepts. London: Routledge.
Swales, J.M. (2004). Research genres: Explorations and applications. Oxford: Oxford University Press.

Tinkler, P. and Jackson, C. (2004). The doctoral examination process. London: Open UniversityPress.

Van Dijk, T.A. (1995). Discourse semantics and ideology. Discourse \& Society, 6 (2), 243-289.

WosenuYimam. (2009). 'Thesis Examination Process in the College of Education/AAU/: Graduate students' Reflection'. In Tirusew Tefera, AkliluDalelo and MekashaKassaye (Eds.) Proceedings of the 1st International Conference on Educational Research for Development. Vol. II (258-274): Addis Ababa. College of Education.

Zewdu, E. (2012). An Investigation into the Research Culture of Addis Ababa University: The Case of Teaching English as a Foreign Language (TEFL) PhD Program. Unpublished PhD Dissertation. Addis Ababa University 